\title{
Spray and Drench Treatments of Paclobutrazol Influence Growth of Dissotis and Tibouchina
}

\author{
Susan M. Hawkins \\ Department of Horticulture, The University of Georgia, 1111 Plant Sciences \\ Building, Athens, GA 30602-7273
}

\author{
John M. Ruter ${ }^{1}$ \\ Department of Horticulture, The University of Georgia, 327 Hoke Smith \\ Building, 1225 Lumpkin Street, Athens, GA 30602
}

Carol D. Robacker

Department of Horticulture, The University of Georgia, 1109 Experiment Street, Georgia Station, Griffin, GA 30223-1797

Additional index words. Melastomataceae, Dissotis rotundifolia, Tibouchina fothergillae $\times$ pilosa, plant growth regulators

\begin{abstract}
Dissotis rotundifolia (Sm.) Triana and Tibouchina fothergillae $\times$ pilosa are members of the Melastomataceae family with high ornamental potential. The growth habits of these species are not ideal for nursery production or shipping. D. rotundifolia grows rapidly and needs frequent pruning. $T$. fothergillae $\times$ pilosa has an open growth habit and could benefit from a more compact form. The effect of the plant growth regulator (PGR) paclobutrazol on $D$. rotundifolia and $T$. fothergillae $\times$ pilosa was assessed to determine whether it could produce plants with a more compact growth habit. Paclobutrazol was applied as a drench and a spray. Drench application was more effective in reducing the growth of both species. Spray application was effective in reducing the growth of $D$. rotundifolia but was not effective on $T$. fothergillae $\times$ pilosa. Neither drench nor spray application delayed or reduced flowering in $D$. rotundifolia. $T$. fothergillae $\times$ pilosa did not flower during the study. For both $D$. rotundifolia and $T$. fothergillae $\times$ pilosa, neither drench nor spray application had an effect on root dry weight. Low-to-medium dosages were effective at controlling plant growth in $D$. rotundifolia and $T$. fothergillae $\times$ pilosa without adverse effects on plants. Drench treatments have more persistent effects on plant growth than spray treatments.
\end{abstract}

Growth habit impacts the aesthetic value of an ornamental and the economics of the crop. Ornamental plants that grow too rampantly in the nursery often need to be pruned back before sale or shipment, causing additional labor costs. An ornamental that has a weak and open growth habit is often damaged during shipping. Although longterm breeding goals for a species or hybrid may include shorter stature and more compact growth, nurseries need interim solutions.

Plant growth regulators are often used to control plant height and growth habit to produce a more marketable plant. PGRs may also be used to promote or retard the onset of flowering. Application of paclobutrazol and chlormequat to pyrethrum (Chrysanthemum cinerariaefolium Vis.) was found to reduce plant height, but also caused plants to produce fewer flowers (Haque et al., 2007). Treatment of azaleas (Rhododendron simsii

Received for publication 2 Feb. 2015. Accepted for publication 19 Mar. 2015.

This paper is part of a thesis submitted by Susan M. Hawkins as part of the fulfillment of a master's degree.

${ }^{1}$ Corresponding author. E-mail: ruter@uga.edu.
Planch.) with both chlormequat and paclobutrazol induced earlier flower bud formation (Christiaens et al., 2012). Treatment of Dissotis plumosa (a synonym for Dissotis rotundifolia) with chlormequat, daminozide, and ancymidol reduced growth in both greenhouse and fieldgrown plants (Criley, 1976). Paclobutrazol applied as a spray delayed flowering time in mini carnation (Dianthus caryophyllus f. spray Hort.) from 15 to $23 \mathrm{~d}$ but increased the number of blooms per flowering shoot (Atanassova et al., 2004). In Hibiscus rosa-sinensis L., paclobutrazol delayed flowering by $22 \mathrm{~d}$ compared with the control treatment (Nazarudin, 2012).

Effects on plant growth and flowering may differ among cultivars. When paclobutrazol was applied to Lilium L.A. hybrids, flowering in 'Royal Respect' was reduced at the highest concentration applied while flowering in 'Ercolano' was unaffected at any dosage. Plant height was also reduced more in 'Royal Respect' than in 'Ercolano' at every concentration of paclobutrazol (Francescangeli et al., 2007).

Effects of PGRs are often strongly dependent on treatment level. Pyrethrum treated at lower doses of 2-chloroethylphosphonic acid decreased both plant height and flower yield. However, in the same study, application of 2-chloroethylphosphonic acid at higher levels also decreased plant height but increased flower yield (Haque et al., 2007). China aster (Callistephus chinensis L. Nees) was found to produce fewer flowers at higher dosages of paclobutrazol (Mishra et al., 2005). In Lupinus varius L., days to flowering and number of flowers were negatively impacted at higher dosages of paclobutrazol by drench while time to flowering was positively impacted at the highest dosage by spray (Karaguzel et al., 2004). High dosages of PGRs may cause plants to cease growing entirely (Johansen et al., 1999).

Dissotis and Tibouchina are two genera in the Melastomataceae family that contains species of ornamental value. However, the growth habit of certain species and hybrids within these genera is not ideal for shipment or for economic nursery production. D. rotundifolia, a species from Africa, is a trailing plant that flowers profusely. The species roots easily and is extremely drought tolerant. D. rotundifolia grows vigorously and requires pruning to maintain it in a saleable state. Severe pruning prevents the species from blooming for several weeks afterward. Tibouchina fothergillae $\times$ pilosa, a hybrid between two South American species, has purple flowers and attractive fuzzy foliage. The branches of $T$. fothergillae $\times$ pilosa have a very open growth habit, making it difficult to ship. Paclobutrazol is a PGR that acts by inhibiting the biosynthesis of gibberellin (Lever, 1986). The compound has low solubility and has been found to persist in soil as long as 12 months after application (Lever, 1986). Paclobutrazol was chosen to test for its potential to control growth in D. rotundifolia and in $T$. fothergillae $\times$ pilosa, as it has been used to control growth in other Melastomataceae species (Abdullah et al., 1998; Johansen et al., 1999; Roberts and Eaton, 1988). The objective of the experiment was to determine the effectiveness of paclobutrazol applied as a drench or as a foliar spray on controlling the growth and flowering of $D$. rotundifolia and $T$. fothergillae $\times$ pilosa.

\section{Materials and Methods}

Cuttings of $D$. rotundifolia and $T$. fothergillae $\times$ pilosa from container-grown plants of the same clone growing in the greenhouse were taken in early Mar. 2013. Stock plants of $D$. rotundifolia were obtained from the Trial Gardens at the University of Georgia (UGA), Athens, GA. Stock plants of $T$. fothergillae xpilosa plants were obtained from the Tifton campus of UGA. Cuttings were treated with

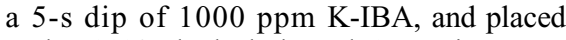
under $30 \%$ shadecloth and $8 \mathrm{~s}$ mist every 10 min until rooted. Cuttings rooted within $28 \mathrm{~d}$ and were transplanted into $2.8-\mathrm{L}$ trade pots with Fafard 3B potting media (Sun Grow Horticulture, Agawam, MA) consisting of Canadian sphagnum peat, processed pine bark, perlite, and vermiculite on 2 Apr. 2013. At this stage, plants were well rooted and beginning to grow vigorously. Paclobutrazol (Bonzi, Uniroyal Chemical Company) was applied as a drench or a spray on 9 Apr. 2013. Plants had been watered to field capacity the afternoon before treatments were applied. Although 
Table 1. Comparison of the effect of paclobutrazol applied as a drench or spray at all rates on growth of Dissotis rotundifolia.

\begin{tabular}{|c|c|c|c|c|c|c|c|c|c|}
\hline Treatment & Final ht $(\mathrm{cm})$ & Ht diff. $(\mathrm{cm})$ & Final width $(\mathrm{cm})$ & Width diff. $(\mathrm{cm})$ & Final GI $\left(\mathrm{cm}^{2}\right)$ & GI diff. $\left(\mathrm{cm}^{2}\right)$ & $\begin{array}{l}\text { Shoot dry } \\
\text { wt (gm) }\end{array}$ & $\begin{array}{l}\text { Root dry } \\
\text { wt (gm) }\end{array}$ & $\begin{array}{l}\text { Root:shoot } \\
\text { ratio }\end{array}$ \\
\hline Spray & $9.2 \mathrm{a}$ & 2.4 & $43.4 \mathrm{a}$ & $25.1 \mathrm{a}$ & $394.1 \mathrm{a}$ & $267.6 \mathrm{a}$ & $10.7 \mathrm{a}$ & 5.1 & $0.5 \mathrm{~b}$ \\
\hline Significance & $*$ & NS & $* *$ & $*$ & $* *$ & $*$ & $*$ & NS & $* *$ \\
\hline
\end{tabular}

**, ${ }^{*}$, ${ }^{\text {ss }}$ Significant $(\mathrm{n}=10)$ at $P \leq 0.01$ or 0.05 , or nonsignificant at $P>0.05$, respectively. GI $=$ growth index; Diff. $=$ difference. Differences in height, width, and GI were calculated as the final measurement less the beginning measurement.

Table 2. Comparison of the effect of all rates of paclobutrazol application for both drench and spray application on growth of Dissotis rotundifolia.

\begin{tabular}{|c|c|c|c|c|c|c|c|c|c|}
\hline $\begin{array}{l}\text { Rate } \\
\text { (mg a.i./pot) }\end{array}$ & Final ht $(\mathrm{cm})$ & Ht diff. $(\mathrm{cm})$ & Final width $(\mathrm{cm})$ & Width diff. $(\mathrm{cm})$ & Final GI $\left(\mathrm{cm}^{2}\right)$ & GI diff. $\left(\mathrm{cm}^{2}\right)$ & $\begin{array}{c}\text { Shoot dry } \\
\text { wt (gm) }\end{array}$ & $\begin{array}{l}\text { Root dry } \\
\text { wt (gm) }\end{array}$ & $\begin{array}{l}\text { Root:shoot } \\
\text { ratio }\end{array}$ \\
\hline 0.125 & $8.4 \mathrm{ab}$ & $1.6 \mathrm{~b}$ & $39.1 \mathrm{~b}$ & $21.5 \mathrm{~b}$ & $333.1 \mathrm{~b}$ & $217.1 \mathrm{~b}$ & 9.6 & 5.3 & $0.66 \mathrm{ab}$ \\
\hline 0.25 & $9.4 \mathrm{a}$ & $2.8 \mathrm{ab}$ & $32.8 \mathrm{bc}$ & $15.1 \mathrm{~b}$ & $313.3 \mathrm{bc}$ & $194.6 \mathrm{~b}$ & 8.6 & 5.5 & $0.68 \mathrm{ab}$ \\
\hline Significance & $*$ & * & $* *$ & $* *$ & $* *$ & $* *$ & NS & NS & $* *$ \\
\hline
\end{tabular}

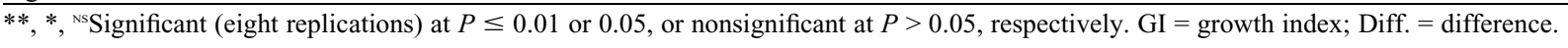

method of treatment was different, the levels of treatment were equivalent in a.i. applied per plant. Paclobutrazol was delivered at the rate of $0,0.125,0.25$, or $0.5 \mathrm{mg}$ a.i. per pot. The same concentration was used for both methods of application so that we could accurately assess the effectiveness of each. Treatments were applied to $10 \mathrm{D}$. rotundifolia and seven T. fothergillae $\times$ pilosa plants per treatment. Plants treated by spray application were sprayed with paclobutrazol to minimal runoff; control plants were sprayed with plain water. Plants treated by drench application were watered with $100 \mathrm{~mL}$ paclobutrazol solution. Control plants for drench treatment were watered with the same volume of tap water instead of the paclobutrazol solution.

Plants were arranged in a completely randomized design by taxon. Height and width measurements were taken weekly for 6 weeks for D. rotundifolia and 8 weeks for $T$. fothergillae $\times$ pilosa. Plant width was measured at the widest part of the plant. The growth index was computed as height $\times$ width. The height, width, and growth index difference were calculated as the difference between the measurements at the beginning and end of the study. Number of flowers per week was also recorded for each $D$. rotundifolia plant. None of the $T$. fothergillae $\times$ pilosa plants bloomed during the period of the study. T. fothergillae xpilosa normally takes longer to bloom after vegetative propagation than $D$. rotundifolia (personal observation), so this was not totally unexpected. The flower index for each week was computed from the number of flowers divided by the growth index. At the end of the experiments, plants were harvested and separated into roots and shoots. Roots were washed in a large container with frequent changes of water before drying. Plants were not potbound, so any root loss due to washing was minimal. Plants were oven dried at $60{ }^{\circ} \mathrm{C}$ to a consistent level of dryness. Roots and shoots were weighed to the nearest $0.01 \mathrm{~g}$. The root: shoot ratio was calculated as root dry weight divided by shoot dry weight from the weight of the dried roots and shoots for each sample.

Data were analyzed using SAS 9.3 (SAS Institute, Inc., Cary, NC) with proc glm. Means separation was done using Tukey's

\section{D. rotundifolia Growth Index (GI) by Week and Treatment}

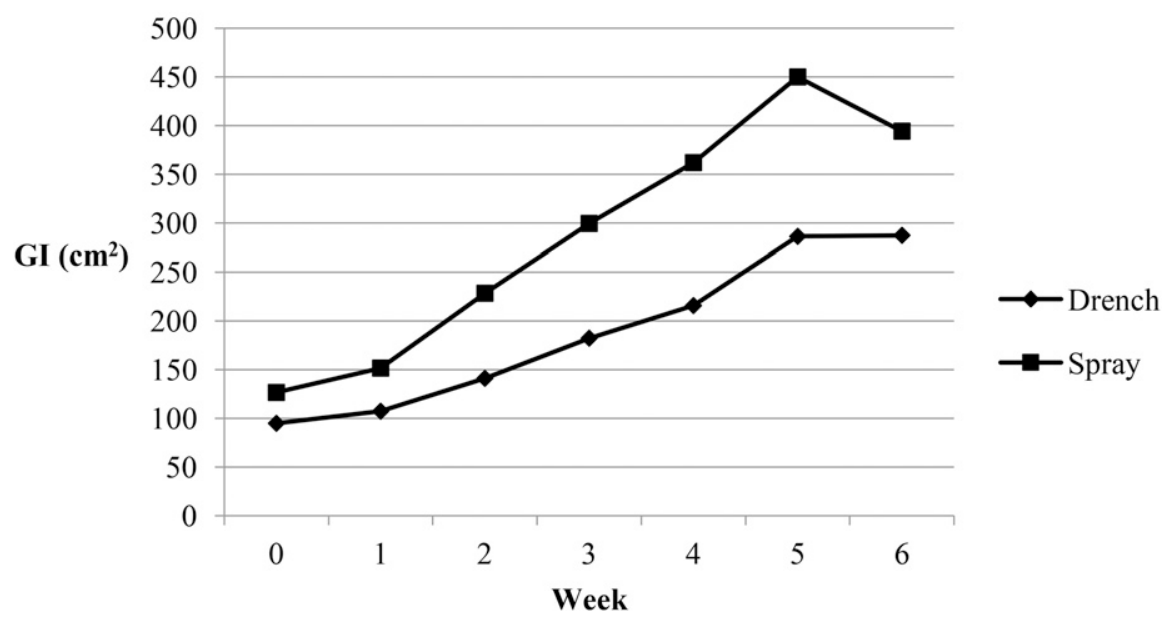

Fig. 1. Influence of paclobutrazol application (drench or spray) averaged over treatment levels on growth of Dissotis rotundifolia over time.

least significant difference $(P<0.05)$ for differences within treatment method.

\section{Results}

No interactions were found between treatment method and rate of application for $D$. rotundifolia. Drench was more effective than spray at controlling the growth of $D$. rotundifolia for every measure of growth except height difference and root dry weight (Table 1). Rate of application had an effect on every measure of growth except shoot dry weight and root dry weight (Table 2). Plants receiving the highest rates of paclobutrazol had a significantly smaller final width and final growth index than plants receiving the lowest rate. The effect of both spray and drench treatments on growth index was most evident 5 weeks after treatment (Fig. 1). Neither drench nor spray treatment had any effect on flower index over the study period (data not shown).

For T. fothergillae $\times$ pilosa, an interaction between treatment method and rate of application was found for all measures of growth except root dry weight and root:shoot ratio (Table 3 ). The clearest effects were found in final width, width difference, and shoot dry weight. Although there was no difference in the effect of drench and spray at the control or the lowest level of treatment with paclobutrazol, drench had a greater effect than spray on reducing the growth of $T$. fothergillae $\times$ pilos $a$ at the medium and highest rates. The difference in effects between drench and spray was not evident until the third week after treatment, and was most marked after the fourth week (Fig. 2). Drench at the highest rate level ( $0.5 \mathrm{mg}$ a.i./pot) resulted in plants that were $83 \%$ shorter than control plants and exhibited a rosette-like growth habit instead of the normal shrub habit of the hybrid (Fig. 3).

\section{Discussion}

Paclobutrazol reduced the growth of $T$. fothergillae xpilosa whether applied as a drench or a spray, although treatments by drench showed the greatest reduction (Table 3). However, plants treated with drench at the highest rate level $(0.5 \mathrm{mg}$ a.i./pot $)$ 
Table 3. Influence of paclobutrazol application (drench or spray) and rate of application on growth of Tibouchina fothergillae $\times$ pilosa.

\begin{tabular}{|c|c|c|c|c|c|c|c|c|c|c|}
\hline Treatment & $\begin{array}{c}\text { Rate } \\
\text { (mg a.i./pot) }\end{array}$ & Final ht $(\mathrm{cm})$ & Ht diff. $(\mathrm{cm})$ & $\begin{array}{c}\text { Final } \\
\text { width }(\mathrm{cm})\end{array}$ & $\begin{array}{c}\text { Width } \\
\text { diff. }(\mathrm{cm})\end{array}$ & $\begin{array}{c}\text { Final } \\
\text { GI }\left(\mathrm{cm}^{2}\right)\end{array}$ & $\begin{array}{l}\text { GI diff. } \\
\left(\mathrm{cm}^{2}\right)\end{array}$ & $\begin{array}{l}\text { Shoot dry } \\
\text { wt (gm) }\end{array}$ & $\begin{array}{l}\text { Root dry } \\
\text { wt (gm) }\end{array}$ & $\begin{array}{l}\text { Root:shoot } \\
\text { ratio }\end{array}$ \\
\hline \multirow{2}{*}{ Drench } & 0.125 & 32.1 & 25.7 & 42.7 & 32.1 & 1,376 & 1,307 & 14.3 & 12.2 & 0.9 \\
\hline & 0.25 & 26.6 & 20.8 & 36.7 & 25.6 & 1,023 & 958 & 8.1 & 7.5 & 0.9 \\
\hline \multirow[t]{3}{*}{ Spray } & 0 & 42.6 & 35.8 & 42.8 & 32.0 & 1,828 & 1,753 & 15.9 & 11.8 & 0.8 \\
\hline & 0.125 & 40.3 & 33.5 & 43.9 & 33.2 & 1,773 & 1,699 & 12.6 & 9.8 & 0.8 \\
\hline & 0.25 & 36.6 & 31.1 & 48.7 & 39.2 & 1,795 & 1,744 & 14.9 & 12.7 & 0.9 \\
\hline \multicolumn{11}{|l|}{ Significance } \\
\hline Treatment & & $* *$ & $* *$ & $* *$ & $* *$ & $* *$ & ** & $* *$ & NS & NS \\
\hline Rate & & $* *$ & $* *$ & NS & NS & $* *$ & ** & $* *$ & NS & $* *$ \\
\hline Treatment $\times$ rate & & $* *$ & $* *$ & $* *$ & $* *$ & $* *$ & $* *$ & $* *$ & NS & NS \\
\hline
\end{tabular}

**, ${ }^{*}{ }^{\text {ss }}$ Significant $(\mathrm{n}=8)$ at $P \leq 0.01$ or 0.05 , or nonsignificant at $P>0.05$, respectively. GI $=$ growth index; Diff. $=$ difference.

\section{T. fothergillae $\times$ pilosa Growth Index (GI) by Week and Treatment}

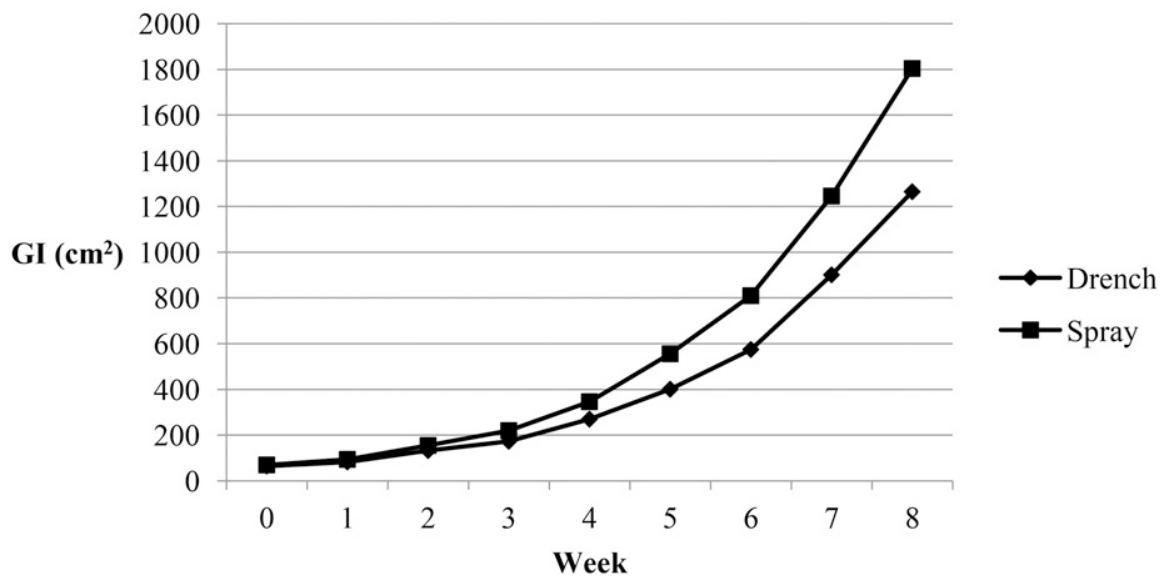

Fig. 2. Influence of paclobutrazol application (drench or spray) averaged over treatment levels on growth of Tibouchina fothergillae $\times$ pilosa over time.

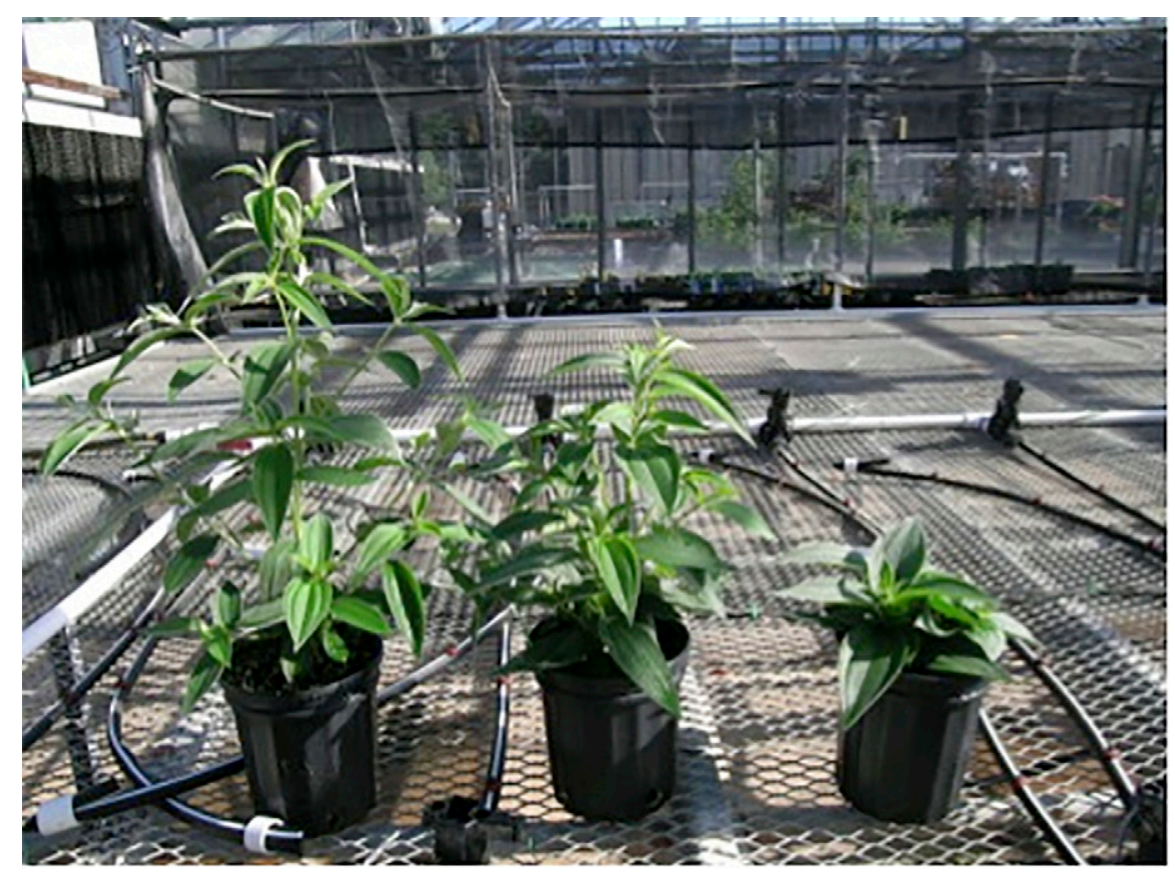

Fig. 3. Tibouchina fothergillae $\times$ pilosa treated with drench application of paclobutrazol at $0,0.25$, and $0.5 \mathrm{mg}$ a.i./pot (left to right). were not of marketable size or growth habit. The persistence of paclobutrazol in the potting substrate (Lever, 1986) likely contributed to the greater effect of drench as compared with spray. Furthermore, $T$. fothergillae $\times$ pilosa has densely pubescent leaves at the apical meristem. When applied as a spray, paclobutrazol is applied to the shoot apex or stem (Intrieri et al., 1987; Lever, 1986). The trichomes on the shoot apex and stems very likely prevented the paclobutrazol from penetrating the epidermis as effectively as it would in a nonpubescent species such as D. rotundifolia.

Method of application has been shown to have an effect in other species, although results seem to be very species dependent. Application of paclobutrazol to bee balm (Monarda didyma L.) by drench reduced growth in height at an increasing rate with higher concentrations while subirrigation treatment did not (Pepin and Cole, 2014). In contrast, paclobutrazol treatment by spray increased height in Oriental lily hybrids more than treatment by drench relative to the control treatment (Puja et al., 2009).

Plant growth regulators may slow growth of roots as well as shoots. Treatment of Tibouchina semidecandra (Dc.) and Melastoma decemfidum Roxb. with high concentrations of paclobutrazol decreased root dry weight (Abdullah et al., 1998). Treatment of butterfly bush (Buddleia davidii Franch. 'Dubonnet') by granular and liquid formulations of paclobutrazol reduced root dry weight at most levels of treatment (Ruter, 1992). Paclobutrazol did not decrease root growth of $D$. rotundifolia or $T$. fothergillae $\times$ pilosa when applied by either drench or spray. However, paclobutrazol did alter the root:shoot ratio in D. rotundifolia. Although not statistically significant, there was a slight decrease in shoot dry weight of $D$. rotundifolia while root dry weight increased by a small amount. These results show that application of paclobutrazol to D. rotundifolia caused partitioning of biomass to favor root over shoot growth. The same effect was found in tomato (Lycopersicon esculentum Mill.) plants treated with paclobutrazol (Berova and Zlatev, 2000).

The effect on roots may be highly species dependent. Paclobutrazol was found to have no effect on root length of Hibiscus rosasinensis L. (Nazarudin, 2012). Density of fine roots was actually stimulated in pin oak (Quercus palustris) and white oak (Quercus alba) by application of paclobutrazol to the soil at their roots (Watson, 1996). 


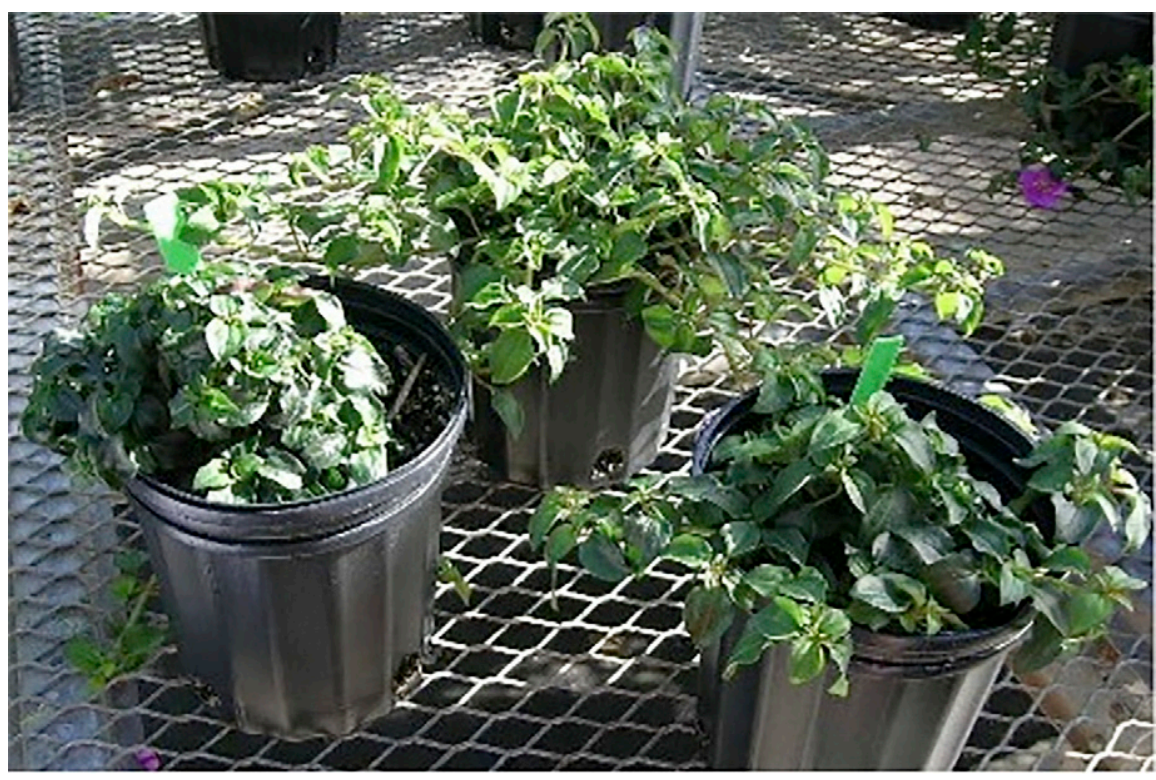

Fig. 4. Dissotis rotundifolia treated with drench application of paclobutrazol at $0.125,0$, and $0.25 \mathrm{mg}$ a.i./ pot (left to right).

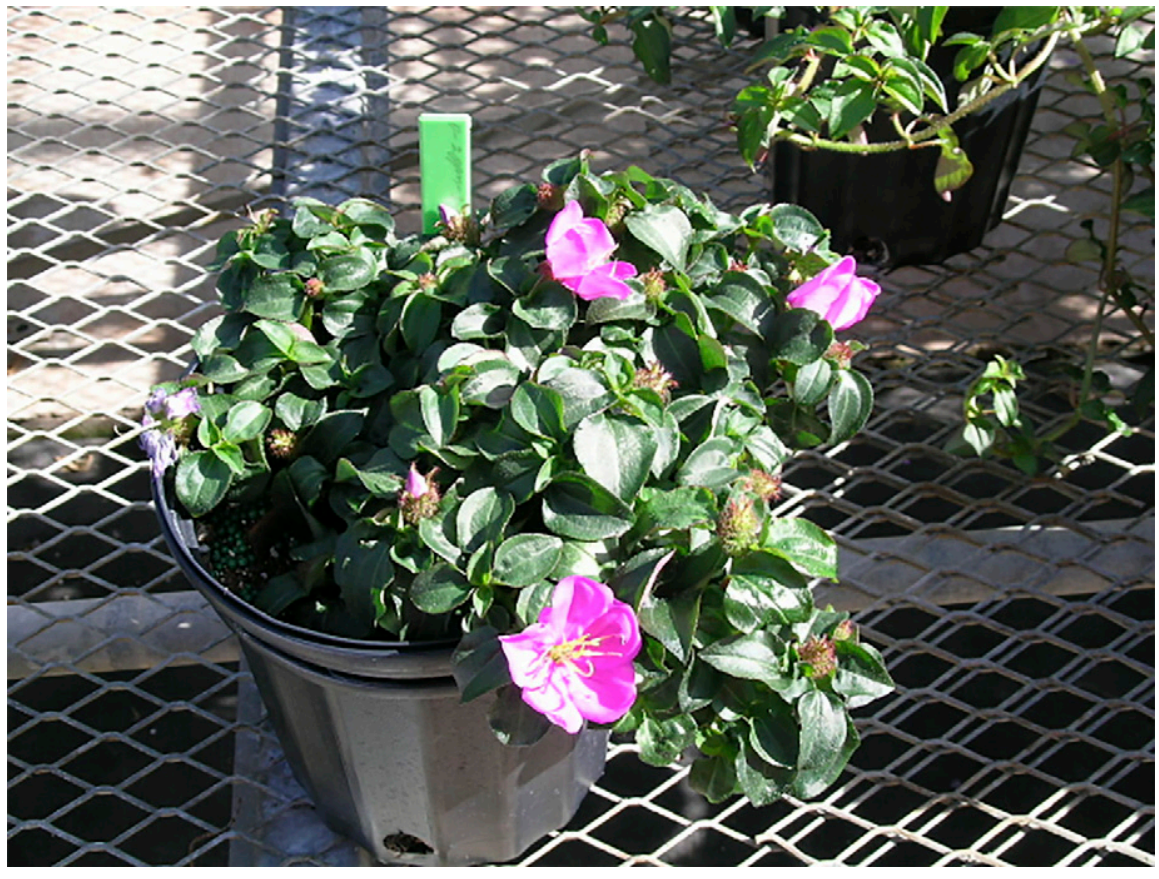

Fig. 5. Dissotis rotundifolia treated with $0.25 \mathrm{mg}$ a.i./pot at blooming stage.

Effect on flowering may also be highly species dependent. Flowering was not delayed in $D$. rotundifolia treated with paclobutrazol by either drench or spray. However, paclobutrazol applied as a drench delayed flowering in Osteospermum ecklonis (DC.) Norl. by 5 to $7 \mathrm{~d}$ (Barnes et al., 2009). Flower bud formation in Oriental lily hybrids was promoted by 7 to $8 \mathrm{~d}$ (Puja et al., 2009). Since delay in flowering could cause plants to be less marketable, a PGR that retards growth while producing either a positive or neutral effect on bloom time is desirable.

Low-to-medium rates of paclobutrazol applied as either drench or spray were effective in reducing the growth of $D$. rotundifolia. (Figs. 4 and 5). Paclobutrazol applied as a drench at the medium rate of $0.25 \mathrm{mg}$ a.i. of drench treatments compared with spray and form are obtained at a drench of $0.25 \mathrm{mg}$ a.1. for $T$. fothergillae $\times$ pilosa and a drench of either 0.125 or $0.25 \mathrm{mg}$ a.i. for D. rotundifolia.

\section{Literature Cited}

Abdullah, T., A.A. Malek, and S.H. Ahmad. 1998 Chemical manipulation of growth and flowering in potted Melastoma decemfidum and Tibouchina semidecandra. Acta Hort. 454:297-301.

Atanassova, B., I. Filipova, and V. Alexieva. 2004 Effect of plant growth regulators Alar, MEIA and paclobutrazol on the phenophase of flowering and some ornamental parameters of minicarnation (D. caryophyllus $f$. spray Hort.) Bulg. J. Agr. Sci. 10:305-309.

Barnes, J., B. Whipker, W. Buhler, and I. McCall. 2009. Osteospermum growth control with paclobutrazol substrate drenches. Proc. 36th Annu. Mtg. of the Plant Growth Regulat. Soc. Amer. Asheville, NC, 2-6 Aug. 2009. Plant Growth Regulat. Soc. Amer., Research Triangle Park.

Berova, M. and Z. Zlatev. 2000. Physiological response and yield of paclobutrazol treated tomato plants (Lycopersicon esculentum Mill.) Plant Growth Regulat. 30:117-123.

Christiaens, A., M.C. Van Labeke, E. Pauwels, B Gobin, E. De Keyser, and J. De Riek. 2012. Flowering quality of azalea (Rhododendron simsii.) following treatments with plant growth regulators. Acta Hort. 1:219-226.

Criley, R.A. 1976. Growth retardants for control of ground covers. Hawaii Agr. Expt. Sta Dept. Paper.

Francescangeli, N., P. Marinangeli, and N. Curvetto. 2007. Paclobutrazol for height control of two Lilium L.A. hybrids grown in pots. Span. J. Agr. Res. 5(3):425-430.

Haque, S., A.H.A. Farooqi, M.M. Gupta, R.S. Sangwan, and A. Khan. 2007. Effect of ethrel, chlormequat chloride and paclobutrazol on growth and pyrethrins accumulation in Chrysanthemum cinerariaefolium Vis. Plant Growth Regulat. 51:263-269.

Intrieri, C., O. Silvestroni, and S. Turri. 1987. Uptake and transport of 14C-paclobutrazol on vinegrape seedlings. Adv. Hort. Sci 1(1):15-19.

Johansen, I.E., S. Findsen, and A.S. Andersen. 1999. Propagation, growth, retardation, flower induction, and postproduction performance of Tibouchina urvilleana (DC.). Cogn. Gartenbauwissenschaft 64:200-205

Karaguzel, O., I. Baktir, S. Cakmakci, and V. Ortacesme. 2004. Growth and flowering responses of Lupinus varius L. to paclobutrazol. HortScience 39:1659-1663.

Lever, B.G. 1986. 'Cultar' - a technical overview. Acta Hort. 179:459-466.

Mishra, D.K., H.R. Mishra, and L.P. Yadava. 2005 Influence of paclobutrazol on early flowering and aesthetic value of China aster (Callistephus chinensis L. Nees). J. Appl. Hort. (Lucknow) 7:34-37.

Nazarudin, A. 2012. Plant growth retardants effect on growth and flowering of potted Hibiscus rosa-sinensis L. J. Trop. Plant Physiol. 4:29-40.

$T$. fothergillae $\times$ pilosa without causing an adverse effect on plant morphology. More labor is involved in applying drench treatments to large numbers of plants than in spraying them, which increases the cost of a single application. Spray applications may need to be repeated to maintain an effective level of paclobutrazol in the plant. Because paclobutrazol persists in the substrate, a single drench application will reduce growth for a longer period of time. This is an advantage treatments if plants must be held in the nursery for several months before sale or shipping. Based on our study, best results in reducing plant growth while preserving marketable size
Pepin, R.E. and J.C. Cole. 2014. Paclobutrazol, uniconazole, or flurprimidol applied at various concentrations as a substrate drench or through subirrigation have little effect on bee balm growth. HortTechnology 24:313-317.

Puja, S., Y.D. Sharma, and Y.C. Gupta. 2009 Effect of paclobutrazol and benzyl adenine on oriental lily hybrids. J. Hort. Sci. 4:128-133.

Roberts, C.M. and G.W. Eaton. 1988. Response of Tibouchina to chlormequat, paclobutrazol, and fertilizer. HortScience 23:1082.

Ruter, J.M. 1992. Growth and flowering response of butterfly-bush to paclobutrazol formulation and rate of application. HortScience 27:929.

Watson, G.W. 1996. Tree root system enhancement with paclobutrazol. J. Arboricult. 22:211-217. 